\title{
Capital Flow Volatility Spillover in Some Selected African Economies
}

\author{
Murtala Abdullahi Kwarah ${ }^{1 *}$, Irrshad Kaseeram ${ }^{1} \&$ Aliyu Sanusi Rafindadi ${ }^{2}$ \\ ${ }^{1}$ Department of Economics, Faculty of Commerce, Administration and Law, University of Zululand, South Africa. \\ Department of Economics, Amadu Bello University, Zaria. Nigeria. \\ *Corresponding Author: qurau30@gmail.com
}

Doi: https://doi.org/10.38157/finance-economics-review.v3i1.272

Citation: Kwarah, M. A., Kaseeram, I., \& Rafindadi, A.S. (2021). Capital Flow Volatility Spillover in Some Selected African Economies, Finance \& Economics Review, 3(1), 1-22. Doi: https://doi.org/10.38157/finance-economics-review.v3i1.272.

\section{Research Article}

\section{Abstract}

Purpose: The study conducted an empirical examination of the link between capital flows and exchange rate by examining the relative influence of FDI and FPI on the exchange rates.

Method: The study proceeded with the EGARCH model and the data sample covering the period from 1990-2016. The data were subjected to cross-country screening. The screening criteria are such that all the data that constitute capital in all sampled countries must have equal sample sizes. The measurement of capital flow in each of the sampled countries was restricted to two categories capital, namely, foreign portfolio investment (FPI) and foreign direct investment (FDI).

Results: The research establishes that the behavior of capital flow volatility spillover of the sample countries' currencies exchange rate differs, with only South Africa's and Morocco's currencies revealing some slight similarity and existence of asymmetric volatility spillover from capital flows to exchange rate. Additionally, the study discloses that capital flows spillover has a considerable effect on exchange rate volatility than harmful spillover. The study also observed that positive shocks associated with capital flow volatility affect exchange rate value in Botswana more than capital outflow. Further positive capital flow spillover impending from capital inflow has a considerable effect on exchange rate volatility than the harmful spillover impending from the capital outflow. Further, the positive capital flow spill over impending from capital inflow significantly affects exchange rate volatility more than the negative spillovers that emanate from the capital outflow.

Implications: This suggests that the monetary policy should consider options that can accelerate capital flow into the Moroccan economy. However, in South Africa for any given quantum of capital flow into the economy, the South African Reserve Bank must use instruments to affect stability; otherwise, the currency exchange rate could remain unstable. Thus, capital withdrawals out of the Egyptian economy will create domestic currency instability.

Keywords: Spill-over, Foreign Direct Investments (FDI), Portfolio Investments (PI), asymmetric, capital flow volatility, Exchange rate volatility. 


\section{Introduction}

Prior, and the aftermath of the financial crisis of 2007, there have been surges of capital flows from international investors into Africa's capital markets. The capital flow surge was the product of Africa's favorable growth prospects, coupled with financial markets' improvement that allows for investment diversification. Ahmad et al. (2012) summarize the expected benefit of capital inflows for the recipient economy, particularly emerging and developing countries, to include poverty alleviation, stimulation of economic growth and development, financing savings and exchange rate gaps, aiding resource allocation, as well as reducing unemployment. It is an ongoing discussion among the development and policy scholars who often argue that emerging and developing economies need substantial capital inflows. The capital required by these developing economies will help to fill the saving and exchange rate gaps created by the rapid rate of capital accumulation. And also, to operate healthy economies that are devoid of widespread poverty. Hence, Africa leads all other continents in its need for external financing. In this regard, researchers and policymakers in the region need to pay special attention to the region's capital movement because of its impact and significant consequences to the recipient countries, particularly those with shallow financial markets.

Mishra (2000) confirms that countries with weak financial markets are vulnerable to large capital inflows and subsequent exchange rate crises. Additionally, several studies document both negative and positive attributes of capital inflows on small-open economies similar to the sample countries in this study (Botswana, Egypt, Morocco, and South Africa).

Mishra et al. (2001) investigated the benefit of portfolio inflows, concluded that the flows are associated with positive capital market development, particularly enabling investors to diversify risk and increase the rate of capital returns. The study further observes that portfolio flows increase investment opportunities and lead to recipient countries' economic growth.

In contrast to the above, Calvo et al. (1996) maintain that capital inflows are mostly converted into the recipient's country's currency, leading to inflationary pressure. It raises the demand for non-tradable commodities. With this, one can conclude that large capital inflows to the countries in question are a mixed blessing. ${ }^{1}$

For further studies in this regard, see Reisen and Soto (2001); Ahmad et al. (2012).

However, during the period of capital surges, most African financial markets undergo a series of deregulations, thus increasing capital inflows to the region, in general, and the countries, in particular. This capital surge is associated with excess volatility and regards as a factor that would have spillover effects on the exchange rate. The extent of the capital flows volatility may differ between countries, even those with similar exchange rate regimes and macroeconomic fundamentals (Jane \& Rose, 2002), thus the need for individual countries' study.

Several studies on the relationship of capital flow and exchange rate in emerging and developing countries, such as Ibara, 2011; Kodongo \& Ojah, 2012; Cambes et al., 2012; Lovcha \& Perez-Laborda, 2013). There is, however, the need for more studies on the relationship between

\footnotetext{
${ }^{1}$ For further studies in this regard see Reisen \& Soto (2001); Ahmad et al. (2012).
} 
capital flow volatility and exchange rate in the selected countries. This gap is what this study intends to fill.

This study aims at examining the spillover effects of the capital flows (foreign direct investment [FDI] and foreign portfolio investment [FPI]) on exchange rate. The EGARCH model is employed in this study to assess the effects of capital flows volatility transmission on the foreign exchange market of the selected economies. Thus, establishing the spillover effects of capital flows on the individual sampled country's currency involves introducing the forms of capital flows (FDI and FPI) in the conditional mean equation model. This process causes the average exchange rate to affect foreign portfolio investment's concurrent flows and foreign direct investment-further, the lag exchange rate information account for the past information about the exchange rate of the currencies. The rest of the paper consists of a review of related literature, methodology, data description, discussion of the result, and summary and conclusions.

\section{Capital Flow and Exchange Rate Volatility}

The main concern of this study is to explore the relationship between exchange rate volatility and capital flows (FDI, IPI) and to determine which of the component (FDI, portfolio flow) is more volatile in the countries in question, of South Africa, Morocco, Egypt, and Botswana. Most of the studies on capital flow in emerging and developing countries were conducted towards addressing cross-sectional control of the flow. Thus, economic growth, international reserves accumulation, genuine exchange rate appreciation, inflationary pressures, worsening in the current account, and a boom in bank lending (see Calvo et al., 1993; 1994). The above is usually a result of an increase in capital mobility infrastructure and the rate of capital flows, which in return causes exchange rate volatility, leading to deviations from long-run equilibrium (Kodongo \& Ojah, 2012).

In their empirical study of Latin American countries, Calvo et al. (1993) reveal that foreign factors - including capital flows - accounted for more than $50 \%$ of the variance in real exchange rates and reserves, depending on the country. Another study carried out on Nigeria by Essien \& Onwioduokit (1999) identifies both nominal exchange rate and real income to be among the influencing factors of capital flow.

Kamar \& Bakardzhieva (2005) identify capital flows, lack of adequate investments in the capital market, capital flight, and political instability as the key contributors of Egyptian currency volatility (E.G. pound) after the Egyptian central bank announced a free-floating regime in 2002. Further, Chakraborty (2001) elucidates the effects of capital inflows of private foreign capital on some key macroeconomic variables, real and nominal effective exchange rates and exports, foreign currency assets, and wholesale price index, and money supply. He discovers long-run equilibrium relationships between some sets of variables. He also reveals unidirectional causality from private capital inflows to nominal effective exchange rates (both trade-based and export-based), which raises concerns about the Risk-Based Inspection (RBI) strategy in the foreign exchange market. In a related study in India, from 1986-2001, Kohli (2003) observes the effect of capital flows on a range of economic variables such as exchange rates, interest rates, 
foreign exchange reserves, domestic monetary conditions, and financial systems. The study concludes that foreign capital inflow significantly affecting domestic money supply, stock market growth, liquidity, and exchange rate volatility.

Kang et al. (2002), in their empirical analyses of the determinants of capital flow in Korea from 1990-2001 with quarterly data. The research capture cross-country variations in East Asia, and conclude that there is a significant relationship between capital flow and exchange rate volatility, interest rate, inflation rate, and real GDP growth. Similarly Melis \& Bonga-Bonga (2019) in their study, they empirically show, among other things, the importance of global volatility spill over in driving capital flow volatility in the BRICS countries.

Froot \& Ramadorai (2002) establish that investor flows are significant factors for understanding deviations of exchange rates from fundamentals. Despite the situation will not, however, be of much help in determining long-run exchange rate values. Similarly, Due \& Sen (2006) examined the connections between the real exchange rate, the level of fiscal and monetary policy indicators, current account surplus, capital flows, and the volatility of flows. The Granger causality test reveals that the variables are co-integrated into the real exchange rate.

Additionally, a study conducted using Pakistani quarterly data (1991-2007), Abdul (2009) studies the effects of capital inflows on nominal and real effective exchange rate volatilities. He observed a significant causal relationship between foreign capital inflows and exchange rate volatility. He recommended that there is a need for emerging economies to concentrate on managing capital inflows in such a way that they should not fuel the exchange rate volatility. Furthermore, Combes et al. (2012) show that both public and private inflows can directly cause real effective exchange rate appreciation. The study reveals that portfolio flows (equity and debt) are seven times more volatile than foreign direct investment or bank loans. Besides, they discover that public inflows have a minimal effect on exchange rate appreciation. With the use of a de facto measure of exchange rate volatility, they also observed that a more flexible exchange rate would reduce the volatility of the real effective exchange rate caused by capital inflows.

Fốster et al. (2014) analyze the effects of international capital flows volatility on the Brazilian economy. They found that large capital inflows to Brazil contributed to the inflation of asset prices, which hints at asset bubbles and an overvaluation of the exchange rate. Further, Arizala et al. (2018) study identify prominent growth spillover channels in Sub-Saharan Africa to include trade, banking, financial, remittance, investment, fiscal, and security channels, which are the most likely to transmit growth trends across borders.

Tule (2013) the behavior of capital flows in some selected developing countries. His findings confirm that capital flows are pro-cyclical more explicitly in the financial markets of developing countries. Those are countries experiencing asset bubbles and exchange rate volatility during boom periods.

In a more recent study, Ifeakachukwu \& Ditimi (2014) examine the impact and causal relationship between capital flows and exchange rate in Nigeria around 1986-2011. They use Granger causality and error correction modelling techniques and discover no causal relationship between capital flows (FDI and portfolio investment) and exchange rate during 
their study period. Thus, their long-run analysis establishes a negative and positive relationship between FDI and portfolio investment with the exchange rate.

Baden (2011), Stephen \& Sanmi (2011), and Were et al. (2013) conclude that the reality of most developing countries is that often their imports exceed exports visa-via their demand for foreign exchange (U.S. dollar) frequently exceeds supply. This interplay of the invisible hand and subsequent government's regulatory actions seriously aids intensive pressure on the exchange rate. Notably, these situations contribute to the continuous exchange rate instability of AEE as against major currencies (euro, pound, yen, and dollar) that are used mainly for commercial transactions - especially the U.S. dollar.

\section{Components of Capital Flows Relation to Exchange Rate Volatility (FDI and Portfolio flows)}

Capital flows are among the key sources of exchange rate volatility. Large capital inflows are frequently related to inflationary pressures, real exchange rate appreciation, and a weakening in the current account. Similarly, these types of inflows are capable of causing stock market bubbles, extreme expansion in domestic credit, and financial system instability whenever exchange rate appreciation is not well managed. Many scholars are concern about the negative effects of capital inflows. Thus, an economy loses its competitiveness through real exchange rate fluctuation. $^{2}$

For example, appreciation under a flexible exchange rate regime is a result of nominal exchange rate appreciation. In the case of a fixed exchange rate, the real appreciation is the product of inflation rise due to an increase in the money supply (Calvo et al., 1993; Edwards, 1999 Agenor, 1998; Lartey, 2007).

The unstable behavior of the exchange rate weakens competitiveness, broadens the current account deficit, and leads to vulnerability in a financial crisis. This shows that the case of significant appreciation can ignite a sudden stop of capital flows, a negative effect on investment, and create problems for macroeconomic management predominantly in emerging and developing economies. However, financial liberalization is among the measured transmission mechanisms through which events in one country can transfer to another country in a moment. This can be seen in the recent financial systems' reform in African economies, making them vulnerable to fluctuations in the exchange rate.

\subsection{Exchange Rate Volatility and Foreign Direct Investment (FDI)}

Modern exchange rate determination models advocate that all capital inflows (foreign direct investment, portfolio flows, official flows, and remittances) have a comparable influence on exchange rate volatility. For example, studies establish a relationship between exchange rate

\footnotetext{
${ }^{2}$ For example, appreciation under flexible exchange rate regime is a result of nominal exchange rate appreciation. In the case of fixed exchange rate, the real appreciation is the product of inflation rise due to increase in the money supply (Calvo et al., 1993; Edwards, 1999 Agenor, 1998; Lartey, 2007).
} 
volatility and FDI inflows. ${ }^{3}$ Some of them identify FDI as the most effective and most stable form of capital flows to the African region, which can, directly and indirectly, affect economic growth.

Lartey (2007) maintains that foreign direct investment (FDI) causes the least exchange rate volatility. Accam (1997) further observes a significant negative relationship between exchange rate uncertainty and FDI flows. Similarly, Kinda $(2008,2010)$ attests that FDI is a more stable flow than bank lending and portfolio investment. The studies also opine that countries with a better investment climate attract more FDI flow. The flow of FDI could improve local productive capacity and reduce pressure on the exchange rate. In contrast, Ogunlaye (2008) and Saborowski (2009) discover that FDI can aggravate exchange rate volatility in developing countries.

However, some studies attempt to establish the relationship and direction of causality between exchange rate volatility and FDI in individual countries. Edwards (1998) surveyed the link between exchange rate regimes and capital flows and currency crises in emerging economies using Russia as a case study and throughout Asian and Latin American crises of the 1990s. The study reveals that floating exchange rates can be effective and efficient under the appropriate conditions and policies.

Similarly, Boahen, Ntim, \& Luther (2014) examine the causal link between FDI, exchange rate, and interest rate volatility in Ghana. The results confirm that a stable exchange rate improves FDI and that the inflow of FDI improves the exchange rate's stability. Udoh \& Egwaikhide (2008) also examine the effect of exchange rate volatility, inflation uncertainty, and other key macroeconomic variables on FDI in Nigeria. They reveal that both inflation uncertainty and exchange rate volatility negatively correlate with FDI. ${ }^{4}$ Some panel studies, such as Bleaney \& Greenaway (2001), examine the impact of real effective exchange rate volatility on investment and growth for 14 sub-Saharan African (SSA) countries. The study establishes that exchange rate volatility has a substantial and harmful effect on investment. ${ }^{5}$

Thus, the study focuses on the total investment, which includes FDI. For more literature on the exchange rate and investment, see Soleymani \& Akbar (2011) and Goldberg (2009).

Alaba (2003) also examines the exchange rate volatility-FDI nexus for SSA countries using the Nigerian agricultural and manufacturing sectors as case studies. The results show no significant relationship between official market exchange rate volatility and FDI inflows to both sectors.

Ogunleye (2008) also studies the relationship between exchange rate volatility and FDI in nine SSA countries using both country-specific time series and panel model estimation techniques. He discovers that exchange rate volatility limits FDI inflows to the region.

\footnotetext{
3 See for instance Cushman (1985); Cushman (1988); Froot \& Stein (1991); Goldberg and Kolstad (1994); Goldberg (1997); Goldberg \& Klein (1997); Kiyota and Urata (2004); Ruiz (2005) and Ogunlaye (2008)

4 For similar researcher see Ajayi (2004); Khan \& Bamou (2005); Mwega \& Nguga (2005); Osinubi \& Amaghionyeodiwe (2009); Ellahi (2011); Yousaf et al. (2013).

5 Thus, the study focuses on the total investment which includes FDI. For more literature on exchange rate and investment see Soleymani \& Akbar (2011) and Goldberg (2009).
} 
Furthermore, in a study on South Africa's investment activities in the Southern and Eastern African regions, Mowatt \& Zulu (1999) discover that exchange rate is a significant barrier to FDI to countries Zimbabwe, Botswana, and Mozambique.

In a similar study on Southern African countries, Jenkins \& Thomas (2002) find that one-fourth of the total firms surveyed attest that exchange rate risk is a significant determinant of FDI in the region. Though the studies did not analyze the extent to which exchange rate volatility constrains FDI in the countries, it reveals the negative impact of volatility that can generally restrict capital flows FDI inclusive. ${ }^{6}$

\subsection{Exchange Rate Volatility and Portfolio Flows}

Portfolio capital flow (bond and equity flows) is a component of capital flow that is highly related to exchange rate volatility. Studies have revealed exchange rate volatility makes foreign portfolio acquisition (bonds and equities) risky because it is an impediment to international trade; this particularly makes its study of interest to researchers. The literature on the relationship between portfolio flows and exchange rate volatility are well documented and reveal a more coherent result than that of FDI's relationship with exchange rate volatility in term of causality and direction of causality. For example, Eun \& Resnick's (1988) study reveals that exchange rate uncertainties are largely non-diversifiable factor and have adverse impacts on the performance of international portfolios.

Similarly, Choi \& Rajan's (1997) study of seven major developed countries, with the exception of the US, reveal that foreign exchange risk has a significant effect on asset returns.

Fidora et al. (2007) also finds that exchange rate volatility is an essential factor for bilateral equity and bond portfolio home bias. This was corroborated by Borensztein \& Loungani (2011), in their study on comparative analysis on the trends in financial integration within Asia with those in industrialized countries and other regional groups.

Furthermore, Hau \& Rey's (2006) study develops, among other things, a theoretical framework for analysing the inferences of imperfect foreign exchange risk for the correlation arrangement of exchange rate fluctuations and equity returns, vis-a-vis net portfolio, flows. They also include statistical tests to measure the impact of exchange rate uncertainty on international portfolio flows. This is in line with the view in their previous study (Hau \& Rey, 2002), which reveals that a strong correlation exists between equity flows and exchange rate.

Caporale et al. (2014) observe that the principal idea of exchange rate volatility is that it reduces potential gain by raising transaction costs from international diversification, which occurs through the acquisition of foreign securities, such as bonds and equities risk, which in turn negatively affects international portfolio flows.

In another study on exchange rate uncertainty and international portfolio flows, Caporale et al. (2015) discover that the effect of exchange rate uncertainty is negative on net equity flows in the Euro area (UK and Sweden) and positive in Australia. The input on net bond flows is also negative in all the countries in the sample (Australia, the Euro area, Japan, Sweden and the UK),

${ }^{6}$ Though the studies did not analyse the extent to which exchange rate volatility constrains FDI in the countries, it reveals the negative impact of volatility that can generally restrict capital flows FDI inclusive. 
except in Canada where it is positive. ${ }^{7}$ The study reveals that there is quite a strong relationship between exchange rate volatility and international portfolio flows. It is clear that the negative impact of exchange rate volatility on portfolio flows (both equity and bond flows) cannot be overemphasized. Owing to this fact, international market participants usually avert risk by appropriately responding to exchange rate uncertainties.

\section{Methodology}

The study will proceed with the application of the preferred EGARCH model. The conditional mean equation is specified according to the following law of motion:

$$
e x_{t}=\Psi_{t}+\beta^{\prime} e x_{t-1}+\xi_{t}
$$

To establish the spillover effect of capital flow on domestic currencies' exchange rate for each of the country various capitals in the conditional mean equation model are introduced:

$$
e x_{t}=\omega_{t}+\lambda^{\prime} e x_{t-1}+\vartheta f p i_{t}+\alpha f d i_{t}+s_{t}
$$

The conditional mean equations in 1 and 2 mean that each country's domestic currency's average exchange rate depends on the current foreign portfolio investment flow $\left(f p i_{t}\right)$ and that of foreign direct investment $\left(f d i_{t}\right)$. The lag exchange rate $e x_{t-1}$, accounts for the past information about the exchange rate of the currencies (good and bad news, which means appreciation and depreciation of currencies, respectively).

$$
\begin{aligned}
& \xi_{t} \mid \Omega_{t, \xi} \sim \operatorname{iid}\left(0, \sigma_{t, \xi}^{2}\right) \\
& \aleph_{t} \mid \Omega_{t, \S} \sim \operatorname{iid}\left(0, \sigma_{t, \S}^{2}\right)
\end{aligned}
$$

$\sigma_{t, \beta-j}^{2}$ and $\Omega_{t, \beta}$ is the information sets on which the residuals of exchange rate depend is conditioned. The conditional variance equation is presented in equation 3 and 4 respectively.

$$
\begin{aligned}
& \log \left(\sigma_{t, \xi}^{2}\right)=\Pi+\sum_{j=1}^{q} \phi_{j, \varepsilon}\left|\frac{\xi_{t-j}}{\sqrt{\sigma_{\xi, t-j}^{2}}}\right|+\sum_{j=1}^{q} \tau_{j, \xi} \frac{\xi_{t-j}}{\sqrt{\sigma_{\xi, t-j}^{2}}}+\sum_{i=1}^{p} \mu_{i} \log \left(\sigma_{\xi, t-j}^{2}\right) \\
& \log \left(\sigma_{t, \AA}^{2}\right)=\Pi+\sum_{j=1}^{q} \phi_{j, \epsilon}\left|\frac{\epsilon_{t-j}}{\sqrt{\sigma_{\epsilon, t-j}^{2}}}\right|+\sum_{j=1}^{q} \tau_{j, \epsilon} \frac{\oiint_{t-j}}{\sqrt{\sigma_{s, t-j}^{2}}}+\sum_{i=1}^{p} \pi_{i} \log \left(\sigma_{\phi, t-j}^{2}\right)
\end{aligned}
$$

The EGARCH specification in equations 3 and 4 bear an exponential leverage effect, and hence the estimates will be consistently optimistic. Similarly, the specification also accounts for the existence of threshold effects in the portfolio investment. The hypothesis that follows is that $\mathrm{t} \tau_{j}<0$ when the good news about exchange rate (positive shocks) generates less volatility spillover than bad news (negative shocks).

\section{Data}

The data that were used were drawn from the International Monetary Fund (IMF) archive 2016. The quarterly data spanned from 1990q1 to 2016q1 for all the samples of countries drawn. The data were subjected to cross-country screening. The screening criteria are such that all the data

${ }^{7}$ For more studies on the relation between exchange rate volatility and portfolio flows see Borensztein \& Loungani (2011); Batten \& Vo (2010); Daly \& Vo (2013) and Mishra (2011).

8 Published by Research \& Innovation Initiative, 3112 Jarvis Ave, Warren, MI 48091, USA 
that constitute capital in all sampled countries must have equal sample sizes. There are two justifications for screening: firstly, because the sampled counties are not pooled together. ${ }^{8}$ This would have provided the advantage of using unequal series across sampled countries. Secondly, African countries have a problem with the non-synchronization of data, especially in interest variables. The study ensured that the samples of countries used in the study were constrained to $1990 \mathrm{q} 1$ to $2016 \mathrm{q} 1$ due to data availability for all four counties within this sample period.

The measurement of capital flow in each of the sampled countries was restricted to two categories capital, namely, foreign portfolio investment (FPI) and foreign direct investment (FDI). The lack and irregular data necessarily imposed this restriction within the sampled period and across sampled countries.

All capital measured was indexed into U.S. dollars. The justification of this indexation resides in the global benchmarking of international transactions in the U.S. dollar. Similarly, the data on exchange rates across the countries under review are based on each country's domestic country exchange rate against the U.S. dollar.

\section{Results and discussion}

Having established the EGARCH model's superiority over other competing autoregressive conditional heteroscedasticity models, the study, therefore, precedes by applying the EGARCH in investigating the linkage between capital flow and exchange rate. To estimate the empirical EGARCH model, the study begins with determining the optimal model that appropriately fits the specification presented in the preceding section.

The optimal model selection was determined based on the three information criteria (i.e., AIC, SIC, and HQC). The result presented in Table 1 shows that all three standards are consistent with each other in determining the optimal model for each country.

In the case of Botswana, the model with EGARCH $(1,3)$ has the lowest selection criteria (i.e., with the minimum value of AIC (0.3799), SIC (0.6404), and HQC (0.4853). Hence the analysis will be restricted to the optimal model. Thus, EGARCH $(1,3)$ is the optimal model that conforms to the conditional mean and variance, consequently, most appropriate. In this case, the volatility has more GARCH effects than the ARCH effect.

Egypt exhibits more ARCH effect in the optimal model, and hence the optimal model in this was found to be EGARCH $(4,1)$ as its AIC (0.2453), SIC (0.5318), and HQC (0.3612) values are the lowest. The result also suggests that the optimal model for Morocco and South Africa has the same structure of volatility (i.e., $\operatorname{EGARCH}(1,1)$ ) as indicated in the table1 for both countries AIC, SIC, and HQC statistics to have the minimum value.

Except for Morocco and South Africa, which bear the exact EGARCH specification, the optimal model selection test result suggests unique specifications of the EGARCH models for Botswana and Egypt. This means that the behavior of capital flow volatility spillover to respective countries' currency exchange rate is distinct, even though Morocco and South Africa are

8 This would have provided the advantage of using unequal series across sampled countries. 
somewhat similar. This could be attributed to unique peculiarities inherent in each country's capital market.

Table 1: Result of optimal model

\begin{tabular}{|ccccc|}
\hline Botswana: & EGARCH (1,1) & EGARCH (2,1) & EGARCH (1,2) & EGARCH (1,3) \\
\hline AIC & 0.4395 & 0.4459 & 0.4307 & $\mathbf{0 . 3 7 9 9}$ \\
SIC & 0.6479 & 0.6803 & 0.6651 & $\mathbf{0 . 6 4 0 4}$ \\
HQC & 0.5239 & 0.5408 & 0.5256 & $\mathbf{0 . 4 8 5 3}$ \\
\hline Egypt: & EGARCH (1,1) & EGARCH (2,1) & EGARCH (1,2) & $\mathbf{0 . 2 4 5 3}$ \\
\hline AIC & 0.5547 & 0.3638 & 0.3392 & $\mathbf{0 . 5 3 1 8}$ \\
SIC & 0.7631 & 0.5983 & 0.5997 & $\mathbf{0 . 3 6 1 2}$ \\
HQC & 0.6391 & 0.4587 & 0.4447 & EGARCH (1,3) \\
\hline Morocco: & EGARCH (1,1) & EGARCH (2,1) & EGARCH (1,2) & 0.3799 \\
\hline AIC & $\mathbf{0 . 2 2 2 8}$ & 0.4459 & & 0.6404 \\
SIC & $\mathbf{0 . 4 2 7 4}$ & 0.6803 & 0.4853 \\
\hline HQC & $\mathbf{0 . 3 0 7 5}$ & 0.5408 & EGARCH (1,2) & EGARCH (1,3) \\
\hline South Africa: & EGARCH (1,1) & EGARCH (2,1) & 0.4307 & 0.3799 \\
\hline AIC & $\mathbf{- 2 . 8 6 7 8}$ & 0.4459 & 0.6651 & 0.6404 \\
SIC & $\mathbf{- 2 . 6 5 9 4}$ & 0.6803 & 0.5256 & 0.4853 \\
\hline HQC & $\mathbf{- 2 . 7 8 3 4}$ & 0.5408 & ER & \\
\hline
\end{tabular}

Source: Author's computation. Note all the AIC, SIC and HQC statistics with the minimum value are bolded.

The following section proceeds with the analysis of the estimated result.

\section{Capital Flow Volatility Spill over to Exchange Rate}

The result of capital flow volatility spill over for each country is presented in tables 2 to 5 , of which each table comprises two panels. The top panels estimate the conditional mean equation, while the lower panels are estimates of the dependent variance model.

The conditional mean equation results from table 2 indicate that the average changes in the value of Botswana's currency (pula, BWP) depend on the average change in portfolio investment, foreign direct investment, and past information about the exchange rate value of the pula. However, the pula's average weight is not significantly conditional on the average change in the flow of both FDI and FPI in Botswana. This finding is consistent with that of Korea. See, Choi, Chung \& Kim (2012).

Table 2: Result of capital flow volatility spillover to exchange rate in Botswana

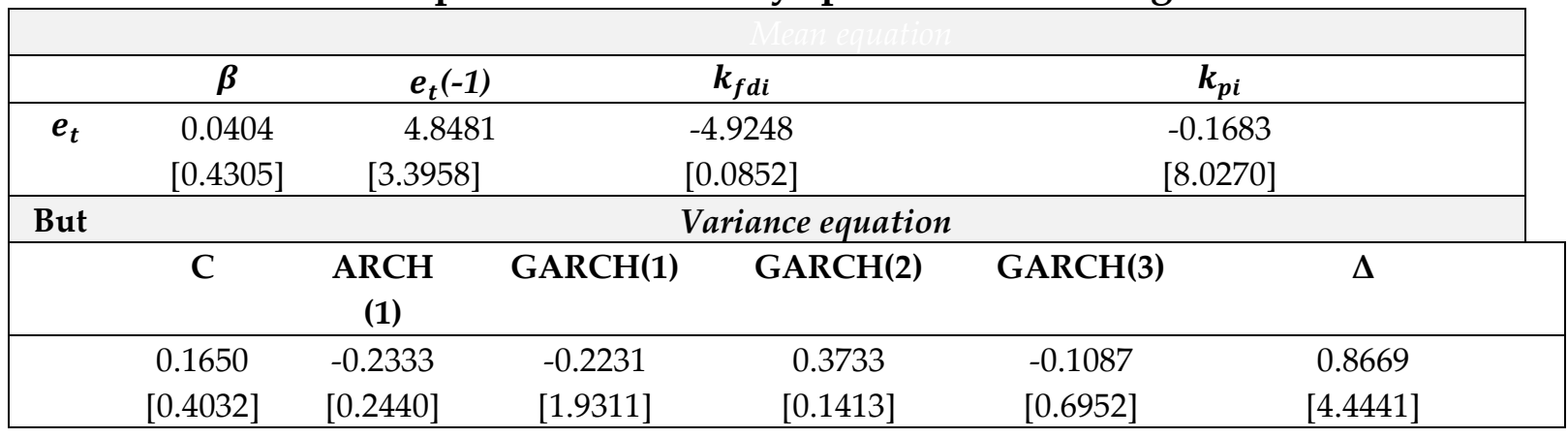

Source: Author's computation. . 
This finding implies that the average exchange rate value of the pula over time is more conditional upon changes in the net flow from portfolio investment into Botswana and the information about the relative importance of the past country's currency value. The relativity in the past value is predicated on the currency's appreciation or depreciation information in the long run.

The result from the conditional variance equation shows the spillover effect from capital flow volatility to exchange rate. Besides the leverage effect in the volatility spillover from capital flow, the result indicates that the ARCH term's coefficient, which accounts for self-induced volatility, was found not to be statistically significant; on the other hand, the result depicts the presence of the GARCH effect. Thus, the result discovers the leverage effect to be negative. The outcome of this finding has two important implications. Firstly, it means that there is the existence of asymmetric volatility spillover from capital flow to exchange rate. The second implication is that positive capital flow spillover has a more significant effect on exchange rate volatility than negative spillover. This means that capital flow volatility attributed to inflow (positive shock) will have a far-reaching impact on the volatility of the pula's exchange rate value than capital outflow (negative shock).

The cumulative effect of capital flow spillover on the exchange rate's conditional variance is captured by the sum of both ARCH and GARCH effects. The individual impact gives somewhat mixed exchange rate responses, even though the conditional variation on the pula exchange rate appears to be attributed more to the GARCH effect than the ARCH effect. Thus, the cumulative effect provides more definitive evidence about the net spillover effect of capital flow on exchange rate volatility.

The result indicates in table 2 that the cumulative sum of ARCH and GARCH is less than unity and negative. This suggests that the overall spillover effect of capital flow on Botswana's currency reduces, and the net impact on the volatility of the exchange rate dissipates contemporaneously. In light of these results, a monetary authority's outlook on capital flow is effective in the short run. Hence, they tend to adopt appropriate policy stances consistently in response to anticipated short-term volatilities.

In the case of Morocco, as presented in table 3, the result shows that the FDI has a positive leverage coefficient. Still, overall it reveals that the leverage effect does not exist. This means that bad news that could lead to the dirham's depreciation doesn't outweigh the good news that could lead to the dirham's appreciation. Thus, there is no asymmetry between the bad and the good news on Morocco's currency dirham's exchange rate value since both coefficients of FDI and FPI were found to be insignificant. This suggests the probability of FDI to have a positive leverage effect is meager, likewise portfolio. However, the portfolio investment indicates a negative impact on the mean value of the dirham. The effect of past information on the dirham positively impacts the dirham's current mean value. This means that past changes in terms of appreciation (depreciation) positively impact the money's current exchange rate value. Meanwhile, the average changes in the capital flow of both FDI and portfolio appear insignificant in affecting the mean changes in the dirham's exchange rate. 
This result indicates that the Moroccan monetary authority could have some capital flow controls, probably with the view of mitigating the effect it may have on the dirham's exchange rate. This corroborates evidence from India, Indonesia and Thailand (Caporale, Ali, Spagnolo \& Spagnolo, 2017).

Table 3: Result of capital flow volatility spill-over to exchange rate in Morocco

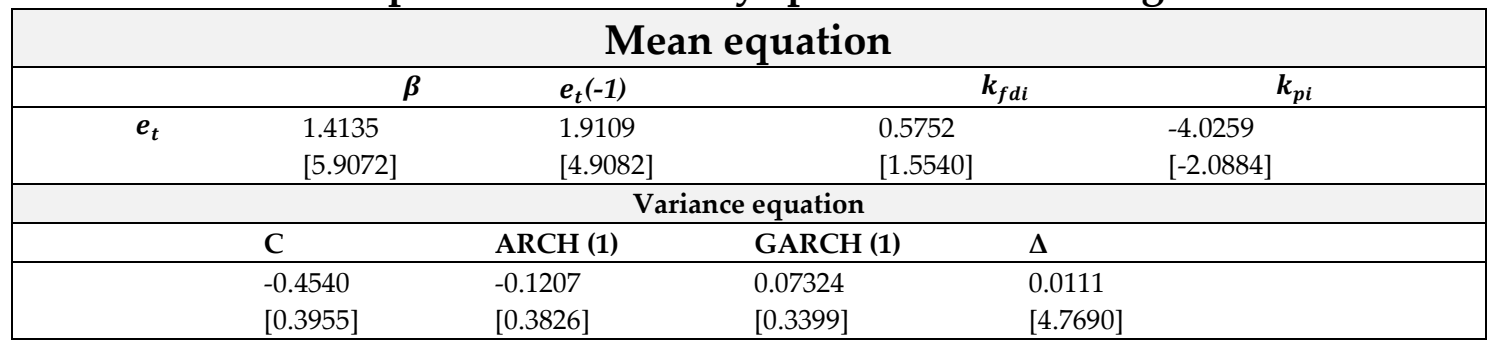

Source: Author's computation.

The dirham's conditional variance estimates show that the spillover effect from capital flow volatility to the dirham's exchange rate is asymmetrical. The volatility spillover's leverage effect indicates that positive spillover influences dirham's exchange rate than negative spillover. This means that capital inflow's positive capital flow spillover significantly affects exchange rate volatility than negative spillover from the capital outflow. Hence, the dirham's exchange rate value can substantially be improved, even though it is more volatile when there is more capital inflow into the Moroccan economy. These suggest that the monetary policy should consider an option that can accelerate capital flow into the economy.

The evidence from the aggregate capital flow spillover to the variance of the Moroccan dirham's exchange rate, as indicated by the cumulating of both ARCH and GARCH effect, was not very strong. This means there is no persistence in volatility in the dirham's exchange rate whenever capital flow spills to exchange rate movement. Although both coefficients of the ARCH and GARCH effect in the capital volatility spillover are negative and positive, the sum of both estimates remains less than 1 . This suggests that the volatility spillover that accentuates volatility in the exchange rate of dirham dissipates and vanishes. The result indicates that both coefficients of the ARCH and GARCH effects are not significant. That means capital flow movement and the resulting net effect do not significantly contribute to the exchange rate fluctuations over time.

For the South African currency (rand), the result of the conditional mean equation in Table 4 shows that the average effect of FDI and the past information about the relative value of the currency significantly impact the rand's current exchange rate value. However, the moderate impact of portfolio investment on the exchange rate of the rand is insignificant. These suggest that, on average, FDI is more important in contributing to the appreciation of the exchange rate of the South African rand than the average effect portfolio investment.

One probable implication of this finding is that FDI inflows into the South African economy remain longer because they are more illiquid than the portfolio and contribute to the currency stability before the investors move their investment out of an economy.

The effect of past information on the rand has a positive impact on the exchange rate's current mean value. This means that past changes in terms of appreciation (or depreciation) of the rand have a positive effect on the currency's current exchange rate value. 
Table 4: Result of capital flow volatility spill-over to exchange rate in South Africa

\begin{tabular}{|c|c|c|c|c|}
\hline \multicolumn{5}{|c|}{ Mean equation } \\
\hline & $\beta$ & $e_{t}(-1)$ & $\boldsymbol{k}_{f d i}$ & $\boldsymbol{k}_{p i}$ \\
\hline$e_{t}$ & $\begin{array}{l}-0.04143 \\
{[0.1014]} \\
\end{array}$ & $\begin{array}{l}1.7138 \\
{[4.6353]}\end{array}$ & $\begin{array}{l}1.8450 \\
{[5.6660]}\end{array}$ & $\begin{array}{l}0.1648 \\
{[1.3550]}\end{array}$ \\
\hline \multicolumn{5}{|c|}{ Variance equation } \\
\hline $\mathrm{C}$ & & ARCH (1) & GARCH (1) & $\Delta$ \\
\hline $\begin{array}{l}-6.6364^{* * *} \\
{[0.0011]}\end{array}$ & & $\begin{array}{l}1.2863 \\
{[5.8708]}\end{array}$ & $\begin{array}{l}0.0172 \\
{[0.9223]}\end{array}$ & $\begin{array}{l}0.0204 \\
{[0.9533]}\end{array}$ \\
\hline
\end{tabular}

The variability in the rand's current exchange rate indicates some evidence of volatility spillover that emanates from capital flow volatility. Also, the result suggests the presence of asymmetric spillover from the capital flow. This asymmetry is significant, and the volatility spillover is leveraging more on the capital inflow than outflow. This implies that positive shocks associated with the influx of capital into the South African economy are more significant than the negative shocks caused by capital outflow. Hence, domestic currency exchange rate volatility can be linked to inflows which keep the rand appreciating in response to the capital's direction.

Meanwhile, due to the currency's rapid response to the capital movement, the spillover shows no sign of slowing down. This means the volatility spillover from capital flow to the exchange rate of the rand is spontaneous.

Furthermore, the result indicates that as positive capital flow spillover coming from capital inflow has a more significant effect on exchange rate volatility than negative spillover that arises from capital outflow, this finding conforms to the empirical evidence from Singapore as found in Bala \& Premaratne (2004). This means monetary authority must pay attention to economic outlook when making monetary policy decisions.

Unlike Botswana's pula, the volatility spillover from the capital flow to the rand's exchange rate is persistent over time. This means that for any given quantum of capital flow into the economy, the South African Reserve Bank should be using instruments to affect stability; otherwise, the currency exchange rate could remain unstable.

The empirical evidence from Egypt contrasts with what was obtained in Botswana. The case in Egypt shows that the conditional mean equation gives an overall positive average effect on FDI and portfolio investment. The impact of past information on the country's currency pound's average exchange rate value was also positive. This means that net capital flow positively affects the average exchange rate value of the Egyptian domestic currency (Egyptian pound, EGP). However, in terms of magnitude, FDI flow has a more significant effect on the pound's average value than portfolio flows. This indicates the relative importance FDI has in appreciating the exchange rate value of the pound.

Factors such as favorable monetary policy (a higher interest rate relative to that of the rest of the world), coupled with a good investment climate characterized by less risk and uncertainties, could inhibit capital outflow. Hence, the Egyptian central bank may better achieve its intermediate target of exchange rate stability. 
Table 5: Result of capital flow volatility spillover to exchange rate in Egypt

\begin{tabular}{|c|c|c|c|c|c|c|}
\hline \multicolumn{7}{|c|}{ Mean equation } \\
\hline & 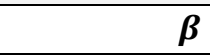 & \multicolumn{2}{|c|}{$e_{t}(-1)$} & $\boldsymbol{k}_{f d i}$ & \multicolumn{2}{|c|}{$\boldsymbol{k}_{p i}$} \\
\hline$e_{t}$ & $\begin{array}{l}-0.0166 \\
{[0.4493]}\end{array}$ & \multicolumn{2}{|c|}{$\begin{array}{l}0.4480 \\
{[4.1084]}\end{array}$} & $\begin{array}{l}0.5030 \\
{[3.7141]}\end{array}$ & $\begin{array}{l}0.0146 \\
{[1.1550]}\end{array}$ & \\
\hline \multicolumn{7}{|c|}{ Variance equation } \\
\hline $\mathrm{C}$ & ARCH (1) & ARCH (2) & ARCH (3) & ARCH (4) & GARCH (1) & $\Delta$ \\
\hline $\begin{array}{l}-1.3458 \\
{[0.0002]}\end{array}$ & $\begin{array}{l}0.2351 \\
{[0.4047]}\end{array}$ & $\begin{array}{l}-1.5516 \\
{[-3.5115]}\end{array}$ & $\begin{array}{l}-0.8980 \\
{[3.7678]}\end{array}$ & $\begin{array}{l}-1.4135 \\
{[-5.9072]}\end{array}$ & $\begin{array}{l}1.9109 \\
{[4.9083]}\end{array}$ & $\begin{array}{l}-0.1644 \\
{[0.5255]}\end{array}$ \\
\hline
\end{tabular}

Source: Author's computation.

Unlike Botswana, Morocco, and South Africa, the Egyptian pound's volatility behavior exhibits some uniqueness (compared to the other emerging African economies under review). A prominent feature in the Egyptian currency's volatility behavior is the negative asymmetric capital flow volatility spillover to the Egyptian pound exchange rate value. This negative asymmetric capital flow spillover means that negative spillover that is accentuated by the outflow of capital has a far more significant effect on exchange rate volatility of the pounds than the positive spillover effect coming from the inflow of money. This means that capital flow volatility, which is attributable to outflow (negative shock), has a far-reaching impact in amplifying the volatility of the Egyptian pound's exchange rate value than capital inflow (positive shock).

Thus, this implies that capital withdrawals out of the Egyptian economy create domestic currency instability. A sudden capital inflow that might reduce the net effect of outflow has the propensity to dampen the volatility of the exchange rate. This shows that a period of intense capital outflow can be managed by monetary policy (tightening) that attracts capital inflow or perhaps impedes flow.

In assessing the aggregate effect of capital flow spillover on conditional variance of the Egyptian pound exchange rate, as captured by the sum of both the ARCH and GARCH effect in the model, the result shows that the GARCH effect the ARCH (1) are both positive. However, the remaining $\mathrm{ARCH}$ effect on the exchange rate, as captured by $\mathrm{ARCH}(2), \mathrm{ARCH}(3)$, and $\mathrm{ARCH}$ (4), are found to be all negative, the magnitude of which is more significant than those $\mathrm{ARCH}$ effects which were found to be positive.

Hence, the exchange rate's cumulative net value is less than 1, suggesting that the overall spillover effect of capital flow on Egyptian pound volatility reduces and dies off contemporaneously. This is consistent with the behavior of spillover effects in Botswana. It is worthy to note that ARCH effects, more than GARCH, primarily characterize the spillover effect from capital flow to exchange rate.

\section{Summary and Conclusion}

The study establishes that the behavior of capital flow volatility spillover regarding sample countries' currencies exchange rate is different. Only South Africa's and Morocco's currencies reveal some similarity. Further, the study concludes the existence of asymmetric volatility spillover from capital flows to exchange rate. Additionally, the capital flows spillover has more significant effects on exchange rate volatility than negative spillover. Thus, capital flow 
volatility is more associated with positive shock affect exchange rate value in Botswana than capital outflow.

It is also discovered that the positive capital flow spillover coming from capital inflow has more significant effects on exchange rate volatility than negative spillover that arises from the capital outflow. Hence, the dirham's exchange rate value can substantially be improved, even though it is more volatile when there is more capital inflow into the Moroccan economy. This suggests that the monetary policy should consider options that can accelerate capital flow into the economy.

Moreover, the positive capital flow spillover coming from capital inflow has greater effects on exchange rate volatility than negative spillover that arises from capital outflow; this finding conforms to Singapore's empirical evidence as found in Bala and Premaratne (2002). This means that a monetary authority must pay attention to the economic outlook when making monetary policy decisions. Unlike Botswana's pula, the volatility spillover from the capital flow to the rand's exchange rate is persistent over time. This means that for any given quantum of capital flow into the economy, the South African Reserve Bank must use instruments to affect stability; otherwise, the currency exchange rate could remain unstable.

Lastly, a prominent feature in Egyptian currency's volatility behavior is the negative asymmetric capital flow volatility spillover to the exchange rate value of Egyptian pounds. This negative asymmetric capital flow spillover means that the negative spillover that is accentuated by an outflow of capital has a far greater effect on the exchange rate volatility of pounds than a positive spillover effect coming from an inflow of capital. This means that the capital flow volatility attributable to outflow (negative shock) has far-reaching consequences in amplifying the volatility of the Egyptian pound's volatility than capital inflow (positive shock).

Thus, this implies that capital withdrawals out of the Egyptian economy create domestic currency instability. A sudden capital inflow that might reduce the net effect of outflow has the propensity to dampen the volatility of the exchange rate. This goes to say that periods of intense capital outflow can be managed by monetary policy (tightening) that attracts capital inflow or perhaps impedes flow.

Author Contributions: Murtala Abdullahi Kwarah conceived the idea and collected data; Irrshad Kaseeram and Sanusi Aliyu Rafindadi fine-tuned the idea, supervise the work and help in the data analyzes; All authors wrote and revised the paper.

Conflict of Interest: The authors declare no conflict of interest.

\section{REFERENCES}

Abdul, R.A. (2009). Capital inflows and exchange rate volatility in Pakistan. International Conference on Applied Economics, 571-578.

Accam, B. (1997). Survey of measurement of exchange rate instability. IMF Staff Papers, (31)2.

Ahmed, S. \& Zlate, A. (2014). Capital flows to emerging market economies: a brave new world? Board of Governors of the Federal Reserve System: International Finance Discussion Papers (Number 1081). 
Finance \& Economics Review 3(1), 2021

Ajayi, S. I. (2004) Determinants of Foreign Direct Investment in Africa: A Survey of the Evidences. A framework paper presented at: The IMF/AERC special workshop on foreign direct investment in Africa. Nairobi, Kenya.

Alaba, O. (2003). Exchange rate uncertainty and foreign direct investment in Nigeria. A Paper Presented at: the WIDER Conference on Sharing Global Prosperity, Helsinki, Finland.

Arizala, F., Bellon, M., MacDonald, M., Mlachila, M., \& Yenice, M. (2018). Regional spillovers in Sub-Saharan Africa exploring different channels. : International Monetary Fund, ISBN 9781484367148. Washington, DC.

Bala, L., \& Premaratne, G. (2004). Volatility spill-over and co-movement: Some new evidence from Singapore. National University of Singapore Working Paper.

Batten, J.A. \& VO, X.V. (2010). The determinants of equity portfolio holdings. Applied Finance and Economics, 20(14), $1125-1132$.

Bleaney, M. \& Greenaway, D. (2001). The impact of terms of trade and real exchange rate volatility on investment and growth in in sub-Saharan Africa. Journal of Development Economics, 65(2), 491-500.

Boahen, A., Ntim, E., \& Luther, A. (2014) Causality analysis of foreign direct investment, exchange rate and interest rate volatility in Ghana. Journal of Economics and Sustainable Development, ISSN 2222-1700 (Paper) ISSN 22222855, (5)9.

Borensztein, M., \& Loungani, M. (2011). Asian financial integration: Trends and interruptions. Retrieved from http://books.google.co.za

Calvo, G. A., Leonardo L., \& Reinhart, C. (1993). Capital inflows and real exchange rate appreciation in Latin America: The Role of External Factors. IMF Staff Papers, 40(3), 108-151.

Calvo, G., Leiderman, L., \& Reinhart, C. (1996). Inflows of capital to developing countries in the 1990s. The Journal of Economic. Retrieved from http://www.jstor.org/stable/2138485

Caporale, G.M., Hunter, J., \& Menla Ali, F. (2014). On the linkages between stock prices and exchange rates: Evidence from the banking crisis of 2007-2010. International Review of Financial Analysis, 33, .87-103.

Caporale, G.M., Menla Ali, F., \& Spagnolo, N. (2015). Exchange rate uncertainty and international portfolio flow: A multivariate GARCH-in-mean approach. Journal of International Money and Finance, 54, 70-92.

Chakraborty, I. (2001). Liberalization of capital flows and the real exchange rate in India: A VAR Analysis. CDS Working Paper, No- 351.

Choi, J.M.J., \& Rajan, M.L. (1997). A joint test of market segmentation and exchange risk factor in international capital markets. Journal of International Business Studies, 28(1), 29-49.

Choi, K., Chung, K., \& Kim, S. (2012). Capital Inflows and Exchange Rate Volatility in Korea. Bank of Korea Working Paper No. 2012-16.

Combes, J., Kinda, T., \& Plane, P. (2012). Capital flows, exchange rate flexibility, and the real exchange rate. Journal of Macroeconomics. Retrieved from http://www.sciencedirect.com

Daly, K., \& VO, X.V. (2013). The determinants of home bias puzzle in equity portfolio investment in Australia. International Review of Financial Analysis, 27, 34-42.

Due, P., \& Sen, P. (2006). Capital flow volatility and exchange rates: The case of India. Centre for Development Economics, Department of Economics, Delhi School of Economics, Working Paper No. 144.

Edwards, S. (1998). Capital flows, real exchange rates, and capital controls: some Latin American experiences. Retrieved from http://www.nber.org/papers/w6800

Ellahi, N. (2011). Exchange rate volatility and foreign direct investment behaviour in Pakistan: A time series analysis with auto regression distributed lag application. African Journal of Business Management. 5(29), 11656- 11661.

Essien, E.A., \& Onwioduokit, E.A. (1999). Capital Flows to Nigeria: Issues and determinants. Central Bank of Nigeria (CBN) Eight Annual Conference of the Zonal Research Units. (p. 88).

Eun, C., \& Resnick, B. (1988). Exchange rate uncertainty, forward contracts, and international portfolio selection. http://doi/10.1111/j.1540-6261.1988.tb02597.x/full

Fidora, M., Fratzscher, M., \& Thimann, C. (2007). Home bias in global bond and equity markets: the role of real exchange rate volatility. Journal of International Money Finance, 26, 631-655.

Forster, M., Jorra, M., \& Tillmann, P. (2014). The dynamics of international capital flows: Results from a dynamic hierarchical factor model. Journal of International Money and Finance, 48, 101-124. 
Froot, K., \& Ramadorai, T. (2002). Currency returns, institutional investors flows, and exchange rate fundamentals. NBER Working Paper, 9101.

Goldberg, L. S., \& Klein, M. W. (1997). Foreign direct investment, trade and real exchange rate linkages in Southeast Asia and Latin America. NBER Working Paper, 6344.

Goldberg, L., \& Kolstad, C. (1994). Foreign direct investment, exchange rate variability and demand uncertainty. Retrieved from http://www.nber.org/papers/w4815

Goldberg, L.S. (1997). Exchange rates and investment response in Latin America. In Cohen, B. J. (Ed.), International Trade and Finance: New Frontiers for Research: Festschrift in Honor of Peter B. Kenen. Cambridge: Cambridge University Press.

Goldberg, L.S. (2009). Exchange rates and foreign direct investment. The Princeton Encyclopedia of the World Economy (pp. 393-396).

Goldberg, P. K., \& Michael M. K. (1997). Goods prices and exchange rates: What have we learned? Journal of Economic Literature, 35, 1243-72.

Hau, H., \& Rey, H. (2002). Exchange rates, equity prices and capital flows. The Review of Financial Studies, 19(1), 273317. Retrieved from https://www.jstor.org/stable/3598037

Hau, H., \& Rey, H. (2006). Exchange rates, equity prices, and capital flows. Review of financial studies. Retrieved from http://rfs.oxfordjournals.org/content/19/1/273.short

Ifeakachukwu, N.P., \& Ditimi, A. (2014) Capital inflows and exchange rate in Nigeria. Mediterranean Journal of Social Sciences, 5(7), (pp. 263-272). Retrieved from http://www.scopus.com

Kamar, B., \& Bakardzhieva, D. (2005). Economic trilemma and exchange rate management in Egypt. Review of Middle East Economics and Finance, 3(2), 91-114.

Kang, J. S., Prati, A., \& Rebucci, A. (2007). Aid, exports, and growth: A time series perspective on the Dutch disease hypothesis. Washington, DC: International Monetary Fund.

Khan, S., \& Bamou, L., (2005) An Analysis of foreign direct investment Flows to Cameroon. A Report presented at the AERC/IMF Special Workshop on Foreign Direct Investment in Africa.

Kinda, T. (2008). Infrastructures. et flux de capitaux privés vers les pays en développement Revue Economique,59(3), 53749.

Kinda, T. (2010). Investment climate and FDI: Firm-level evidence. World Development, 38(4), 498-513.

Kiyota, K., \& Urata, S. (2004). Exchange rate, exchange rate volatility and foreign direct investment. The World Economy, 27(10), 1501-536. Retrieved from https://editorialexpress.com

Kodongo, O., \& Ojah, K. (2012). The dynamic relation between foreign exchange rates and international portfolio flows: Evidence from Africa's capital markets. International Review of Economics \& Finance, 24, 71-87.

Kohli, R., (2003). Capital flows and domestic financial sector in India. Economic Political Weekly 761-68.

Kyriakos, C. N. (2019). Volatile Capital Flows and Economic Growth: The Role of Banking Supervision. Journal of Financial stability, 40, 77-93.

Lartey, E., (2007). Capital inflows and the real exchange rate: An empirical study of sub-Saharan Africa. The Journal of International Trade \& Economic. http://doi/abs/10.1080/09638190701526667

Melis, M., \& Bonga-Bonga, L. (2019). Determinants of global capital volatility in the BRICS grouping. University of Johannesburg, Paper No. 94125. Retrieved from https://mpra.ub.uni-muenchen.de/94125/ MPRA

Mishra, A.V., (2011). Australia's equity home bias and real exchange rate volatility. Review of Quantitative Financial Accounting, 37 (2), 223 - 244.

Mishra, P., Montiel, P., \& Spilimbergo, A. (2010). Monetary transmission in low income countries. IMF Working Paper, no WP/10/223.

Mowatt, R., \& Zulu, T. (1999). Intra-regional private capital flows in Eastern and Southern Africa: A Study of South African investment in the region. Paper presented at a CREFSA/DFI workshop.

Mwega, F. M., \& Rose W. N. (2005) Foreign direct investment in Kenya. A final report submitted to the African Research Economic Research Consortium. Nairobi, Kenya.

Nwosa, P. I., Ugwu E., \& Ehinomen C. (2020). Volatility in Foreign Capital Inflows and Economic Growth in Nigeria. Retrieved from https://dj.univdanubius.ro/index.php/EE/article/view/252/768 
Obadiaru, E., Oloyede, J. A., \& Omankhanlen, A. E. (2018) Stock market volatility spillover in West Africa: Regional and global perspectives. Journal of Applied Economic Sciences 13(6), 1597-1604.

Ogunleye, E. K. (2008a). Exchange rate volatility and foreign direct investment inflows in selected Sub-Sahara African countries, 1970-2005. Ph.D. Thesis, University of Ibadan. Ibadan, Nigeria.

Ogunleye, E. K. (2008b) Exchange rate volatility and foreign direct investment inflows

Osinubi, T. S. \& Amaghionyeodiwe, L.A. (2009). Foreign direct investment and exchange rate volatility in Nigeria. International Journal of Applied Econometrics and Quantitative Studies, 6(2), 84-115.

Ruiz, I. C. (2005). Exchange rate as a determinant of foreign direct investment: Does it really matter? Theoretical aspects, literature review and applied proposal. Ecos de Economía. 21, 153-171. Harare, Southern Africa.

Saborowski, C. (2009). Capital inflows and the real exchange rate: Can financial development cure the Dutch disease? IMF working paper 09/20. Washington, DC: International Monetary Fund.

Soleymani, M., \& Akbari, A. (2011). The relationship between exchange rate uncertainty and investment in some of Sub-Saharan African Countries. International Journal of Business and Public Management, 1(1), 123 -138.

Stephen, B., \& Sanmi, O. (2012). The exchange rate determination in Nigeria: The purchasing power parity option. Mathematical Theory and Modelling, 1(2), 5-22.

Tule, M. K. (2013). Domestic credit growth and international capital flows: Implications for monetary policy management in Nigeria. Retrieved from http://www.cenbank.org/Out/2015/RSD/EFR

Udoh, E., \& Egwaikhide, F. O. (2008). Exchange rate volatility, inflation uncertainty and foreign direct investment in Nigeria. Botswana Journal of Economics, 5(7), 14 -31.

Yousaf, S., Shahzadi, I., Kanwal, B. \& Hassan, M. (2013). Impact of exchange rate volatility on FDI in Pakistan. IOSR Journal of Business Management, 12(1), 79 -86. Attribution (CC BY) license (http://creativecommons.org/licenses/by/4.0/).

\section{Appendix}

\section{A: Botswana}

Dependent Variable: BEX

Method: ML ARCH - Normal distribution (BFGS / Marquardt steps)

Date: 06/11/18 Time: 13:44

Sample (adjusted): 1990Q2 2016Q4

Included observations: 100 after adjustments

Convergence not achieved after 500 iterations

Coefficient covariance computed using outer product of gradients

Presample variance: backcast (parameter $=0.7$ )

$\mathrm{LOG}(\mathrm{GARCH})=\mathrm{C}(5)+\mathrm{C}(6)^{*} \mathrm{ABS}(\mathrm{RESID}(-1) / @ S \mathrm{RT}(\mathrm{GARCH}(-1)))+\mathrm{C}(7)$

${ }^{*} \operatorname{RESID}(-1) / @ S Q R T(G A R C H(-1))+\mathrm{C}(8) * \mathrm{LOG}(\mathrm{GARCH}(-1))+\mathrm{C}(9)$

${ }^{*} \mathrm{LOG}(\mathrm{GARCH}(-2))+\mathrm{C}(10) * \mathrm{LOG}(\mathrm{GARCH}(-3))$ 


\begin{tabular}{lllll}
\hline \hline Variable & Coefficient & Std. Error & z-Statistic & Prob. \\
\hline \hline C & 0.040420 & 0.051278 & 0.788254 & 0.4305 \\
BEX(-1) & 1.013753 & 0.013101 & 77.37749 & 0.0000 \\
BNFDI & $-1.33 E-10$ & $1.44 \mathrm{E}-10$ & -0.923539 & 0.3557 \\
BNPFINV & $-1.80 \mathrm{E}-10$ & $1.06 \mathrm{E}-10$ & -1.692461 & 0.0906 \\
\hline \hline & \multicolumn{5}{l}{ Variance Equation } & \\
\hline \hline C(5) & 0.165007 & 0.197378 & 0.835991 & 0.4032 \\
C(6) & -0.233382 & 0.200337 & -1.164951 & 0.2440 \\
C(7) & 0.360834 & 0.184804 & 1.952529 & 0.0509 \\
C(8) & 0.373340 & 0.253812 & 1.470929 & 0.1413 \\
C(9) & -0.108728 & 0.277530 & -0.391771 & 0.6952 \\
C(10) & 0.696769 & 0.173046 & 4.026498 & 0.0001 \\
\hline \hline R-squared & 0.988409 & Mean dependent var & 7.532228 \\
Adjusted R-squared & 0.988047 & S.D. dependent var & 3.261442 \\
S.E. of regression & 0.356570 & Akaike info criterion & 0.379934 \\
Sum squared resid & 12.20563 & Schwarz criterion & 0.640451 \\
Log likelihood & -8.996685 & Hannan-Quinn criter. & 0.485370 \\
Durbin-Watson stat & 1.867582 & & & \\
\hline \hline
\end{tabular}

\section{B: Egypt}

Dependent Variable: EEX

Method: ML ARCH - Normal distribution (BFGS / Marquardt steps)

Date: 06/11/18 Time: 14:04

Sample (adjusted): 1990Q2 2016Q4

Included observations: 100 after adjustments

Convergence not achieved after 500 iterations

Coefficient covariance computed using outer product of gradients

Presample variance: backcast (parameter $=0.7$ )

$\mathrm{LOG}(\mathrm{GARCH})=\mathrm{C}(5)+\mathrm{C}(6)^{*} \mathrm{ABS}(\mathrm{RESID}(-1) / @ S Q R T(\mathrm{GARCH}(-1)))+\mathrm{C}(7)$

*ABS(RESID(-2)/@SQRT(GARCH(-2))) + C(8)*ABS(RESID(-3)

/@SQRT(GARCH(-3))) + C(9)*ABS(RESID $(-4) / @ S Q R T(G A R C H(-4)))+$ $\mathrm{C}(10)^{*} \operatorname{RESID}(-1) / @ S Q R T(G A R C H(-1))+\mathrm{C}(11)^{*} \operatorname{LOG}(\mathrm{GARCH}(-1))$ 


\begin{tabular}{|c|c|c|c|c|}
\hline Variable & Coefficient & Std. Error & z-Statistic & Prob. \\
\hline $\mathrm{C}$ & -0.016679 & 0.022045 & -0.756567 & 0.4493 \\
\hline $\operatorname{EEX}(-1)$ & 1.026068 & 0.003558 & 288.3433 & 0.0000 \\
\hline ENFDI & 4.37E-11 & $4.45 \mathrm{E}-12$ & 9.810273 & 0.0000 \\
\hline \multirow[t]{2}{*}{ ENPFINV } & $1.10 \mathrm{E}-11$ & $6.67 \mathrm{E}-12$ & 1.641295 & 0.1007 \\
\hline & \multicolumn{4}{|c|}{ Variance Equation } \\
\hline$C(5)$ & -1.345808 & 0.355751 & -3.783004 & 0.0002 \\
\hline$C(6)$ & 0.235161 & 0.282245 & 0.833180 & 0.4047 \\
\hline$C(7)$ & -0.591551 & 0.154205 & -3.836135 & 0.0001 \\
\hline$C(8)$ & -1.331665 & 0.272287 & -4.890672 & 0.0000 \\
\hline$C(9)$ & -0.963161 & 0.354156 & -2.719596 & 0.0065 \\
\hline$C(10)$ & 0.281125 & 0.113310 & 2.481019 & 0.0131 \\
\hline$C(11)$ & -0.164405 & 0.258973 & -0.634835 & 0.5255 \\
\hline R-squared & 0.984821 & \multicolumn{2}{|c|}{ Mean dependent var } & 6.598763 \\
\hline Adjusted R-squared & 0.984347 & \multicolumn{2}{|c|}{ S.D. dependent var } & 2.620024 \\
\hline S.E. of regression & 0.327798 & \multicolumn{2}{|c|}{ Akaike info criterion } & 0.245317 \\
\hline Sum squared resid & 10.31532 & \multicolumn{2}{|c|}{ Schwarz criterion } & 0.531886 \\
\hline Log likelihood & -1.265849 & \multicolumn{2}{|c|}{ Hannan-Quinn criter. } & 0.361296 \\
\hline Durbin-Watson stat & 1.557410 & & & \\
\hline
\end{tabular}

\section{C: Morocco}

Dependent Variable: MEX

Method: ML ARCH - Normal distribution (BFGS / Marquardt steps)

Date: 06/11/18 Time: 14:39

Sample (adjusted): 1990Q2 2016Q4

Included observations: 103 after adjustments

Convergence not achieved after 500 iterations

Coefficient covariance computed using outer product of gradients

Presample variance: backcast (parameter $=0.7$ )

$\mathrm{LOG}(\mathrm{GARCH})=\mathrm{C}(5)+\mathrm{C}(6)^{*} \mathrm{ABS}(\mathrm{RESID}(-1) / @ S Q R T(\mathrm{GARCH}(-1)))+\mathrm{C}(7)$

${ }^{*} \operatorname{RESID}(-1) / @ S Q R T(G A R C H(-1))+\mathrm{C}(8) *$ LOG(GARCH(-1)) 


\begin{tabular}{|c|c|c|c|c|}
\hline Variable & Coefficient & Std. Error & z-Statistic & Prob. \\
\hline $\mathrm{C}$ & 1.566780 & 0.521021 & 3.007134 & 0.0026 \\
\hline $\operatorname{MEX}(-1)$ & 0.884611 & 0.041195 & 21.47355 & 0.0000 \\
\hline MNFDI & $3.38 \mathrm{E}-11$ & $3.59 \mathrm{E}-11$ & 0.942161 & 0.3461 \\
\hline \multirow[t]{2}{*}{ MNPFV } & $-4.76 \mathrm{E}-11$ & $6.91 \mathrm{E}-11$ & -0.688597 & 0.4911 \\
\hline & \multicolumn{4}{|c|}{ Variance Equation } \\
\hline $\mathrm{C}(5)$ & -0.454091 & 0.534415 & -0.849697 & 0.3955 \\
\hline$C(6)$ & -0.120765 & 0.138328 & -0.873029 & 0.3826 \\
\hline $\mathrm{C}(7)$ & 0.073240 & 0.076739 & 0.954404 & 0.3399 \\
\hline$C(8)$ & 0.805807 & 0.175913 & 4.580719 & 0.0000 \\
\hline R-squared & 0.850271 & \multicolumn{2}{|c|}{ Mean dependent var } & 12.97268 \\
\hline Adjusted R-squared & 0.845733 & \multicolumn{2}{|c|}{ S.D. dependent var } & 0.671185 \\
\hline S.E. of regression & 0.263620 & \multicolumn{2}{|c|}{ Akaike info criterion } & 0.222836 \\
\hline Sum squared resid & 6.880056 & \multicolumn{2}{|c|}{ Schwarz criterion } & 0.427475 \\
\hline Log likelihood & -3.476034 & \multicolumn{2}{|c|}{ Hannan-Quinn criter. } & 0.305721 \\
\hline Durbin-Watson stat & 1.840206 & & & \\
\hline
\end{tabular}

\section{D: South Africa}

Dependent Variable: SEX

Method: ML ARCH - Normal distribution (BFGS / Marquardt steps)

Date: 06/11/18 Time: 14:46

Sample (adjusted): 1990Q2 2016Q4

Included observations: 100 after adjustments

Convergence not achieved after 500 iterations

Coefficient covariance computed using outer product of gradients

Presample variance: backcast (parameter $=0.7$ )

$\mathrm{LOG}(\mathrm{GARCH})=\mathrm{C}(5)+\mathrm{C}(6)^{*} \mathrm{ABS}(\mathrm{RESID}(-1) / @ S Q R T(\mathrm{GARCH}(-1)))+\mathrm{C}(7)$

*RESID(-1)/@SQRT(GARCH(-1)) + C(8)*LOG(GARCH(-1)) 
Finance E Economics Review 3(1), 2021

\begin{tabular}{|c|c|c|c|c|}
\hline Variable & Coefficient & Std. Error & z-Statistic & Prob. \\
\hline $\mathrm{C}$ & -0.041439 & 0.025294 & -1.638285 & 0.1014 \\
\hline $\operatorname{SEX}(-1)$ & 1.020541 & 0.008501 & 120.0524 & 0.0000 \\
\hline SNFDIS & $2.68 \mathrm{E}-12$ & $1.30 \mathrm{E}-12$ & 2.060792 & 0.0393 \\
\hline \multirow[t]{2}{*}{ SNPFINV } & 8.95E-13 & 8.94E-13 & 1.000517 & 0.3171 \\
\hline & \multicolumn{4}{|c|}{ Variance Equation } \\
\hline$C(5)$ & -6.636461 & 2.031813 & -3.266276 & 0.0011 \\
\hline$C(6)$ & 1.099732 & 0.209134 & 5.258507 & 0.0000 \\
\hline$C(7)$ & 0.017256 & 0.176806 & 0.097599 & 0.9223 \\
\hline$C(8)$ & 0.020409 & 0.348320 & 0.058592 & 0.9533 \\
\hline R-squared & 0.992207 & \multicolumn{2}{|c|}{ Mean dependent var } & 3.412274 \\
\hline Adjusted R-squared & 0.991964 & \multicolumn{2}{|c|}{ S.D. dependent var } & 0.703172 \\
\hline S.E. of regression & 0.063035 & \multicolumn{2}{|c|}{ Akaike info criterion } & -2.867836 \\
\hline Sum squared resid & 0.381451 & \multicolumn{2}{|c|}{ Schwarz criterion } & -2.659423 \\
\hline Log likelihood & 151.3918 & \multicolumn{2}{|c|}{ Hannan-Quinn criter. } & -2.783488 \\
\hline Durbin-Watson stat & 1.163696 & & & \\
\hline
\end{tabular}

